\title{
Nanangenines: drimane sesquiterpenoids as the dominant metabolite cohort of a novel Australian fungus, Aspergillus nanangensis
}

\author{
Heather J. Lacey ${ }^{1,2}$, Cameron L. M. Gilchrist ${ }^{3}$, Andrew Crombie ${ }^{1}$, John A. Kalaitzis ${ }^{1,4}$, \\ Daniel Vuong ${ }^{1}$, Peter J. Rutledge ${ }^{2}$, Peter Turner ${ }^{2}$, John I. Pitt ${ }^{1}$, Ernest Lacey ${ }^{1,4}$, \\ Yit-Heng Chooi ${ }^{*}$ and Andrew M. Piggott ${ }^{*} 4$
}

\author{
Full Research Paper \\ Address: \\ ${ }^{1}$ Microbial Screening Technologies, Smithfield, NSW 2164, Australia, \\ ${ }^{2}$ School of Chemistry, The University of Sydney, NSW 2006, \\ Australia, ${ }^{3}$ School of Molecular Sciences, The University of Western \\ Australia, WA 6009, Australia and ${ }^{4}$ Department of Molecular \\ Sciences, Macquarie University, NSW 2109, Australia \\ Email: \\ Yit-Heng Chooi* - yitheng.chooi@uwa.edu.au; Andrew M. Piggott ${ }^{*}$ - \\ andrew.piggott@mq.edu.au \\ * Corresponding author \\ Keywords: \\ Aspergillus; biosynthesis; drimane; secondary metabolites; \\ sesquiterpenoid; terpenes
}

Beilstein J. Org. Chem. 2019, 15, 2631-2643.

doi:10.3762/bjoc. 15.256

Received: 22 July 2019

Accepted: 14 October 2019

Published: 05 November 2019

This article is part of the thematic issue "Terpenes".

Guest Editor: J. S. Dickschat

(c) 2019 Lacey et al.; licensee Beilstein-Institut.

License and terms: see end of document.

\begin{abstract}
Chemical investigation of an undescribed Australian fungus, Aspergillus nanangensis, led to the identification of the nanangenines - a family of seven new and three previously reported drimane sesquiterpenoids. The structures of the nanangenines were elucidated by detailed spectroscopic analysis supported by single crystal X-ray diffraction studies. The compounds were assayed for in vitro activity against bacteria, fungi, mammalian cells and plants. Bioinformatics analysis, including comparative analysis with other acyl drimenol-producing Aspergilli, led to the identification of a putative nanangenine biosynthetic gene cluster that corresponds to the proposed biosynthetic pathway for nanangenines.
\end{abstract}

\section{Introduction}

The fungal genus Aspergillus is well recognised as a source of structurally diverse terpenoids comprising monoterpenoids [1], sesquiterpenoids [2-5], diterpenoids [6], sesterterpenoids [7-9], triterpenoids [10] and prenylated polyketide meroterpenoids [11-15] isolated from soil, endophytes and marine strains. Of this genus, A. ustus [16], A. calidoustus [17], A. insuetus [17],

A. insulicola [18], A. bridgeri [18], A. sclerotiorum [19], A. variecolor [19], A. parasiticus [20], A. oryzae [21], A. ochraceus [22], A. pseudodeflectus [17], A. carneus [23] and Aspergillus sp. strain IBWF002-96 [4,5] are biosynthetic sources of the drimane sesquiterpenoids. Drimane sesquiterpenoids, which are derived from a parent $\mathrm{C}_{15}$ pentamethyl- 
trans-decalin skeleton, are known to occur in plants, sponges, molluscs and other fungi as well and possess a wide range of bioactivities [24]. The drimane sesquiterpenoids isolated from Aspergillus spp. have exhibited in vitro anti-inflammatory [5] and antiviral [22] activities as well as cytotoxicity against several mammalian cell lines $[4,16,22]$.

Continuing our chemotaxonomic exploration of unusual Australian species of the genus Aspergillus [25-28], a soil survey was completed in the Kingaroy District of the South Burnett region of South East Queensland. One fungal strain, isolated from soil collected near the town of Nanango, Queensland, showed atypical growth patterns with distinct macro- and micro-morphological differences to other Aspergilli. This strain was considered to be a new species, Aspergillus nanangensis, belonging to the subgenus Circumdati, section Jani. The detailed morphological, genomic and chemotaxonomic characterisation of A. nanangensis will be reported elsewhere in due course. Herein, we report the isolation, structure elucidation and bioassay of a family of drimane sesquiterpenoids from A. nanangensis, which we named the nanangenines. Notably, A. nanangensis distinguishes itself within the genus by the production of terpenoids as the dominant biosynthetic class of secondary metabolites.

\section{Results and Discussion Purification and identification}

The metabolite profile of $A$. nanangensis was examined on a limited range of solid and liquid media suitable for fungal metabolite production. The metabolite profile remained consistent despite variations to the carbon and nitrogen sources across agars and liquid media, but the productivity was superior on grains, notably rice and barley. A search of the UV-vis profiles against our in-house library of type species $(>25,000$ spectra from 2,000 species, including 205 Aspergillus type species) and unidentified but metabolically talented fungi ( $>60,000$ spectra from 3,000 species) returned no similar metabolite cohorts, suggesting an unknown species. Individual retention time/ UV-vis searches of the dominant 15 secondary metabolites against our in-house pure metabolite library (>7,100 standards) also failed to provide a single known secondary metabolite, further suggesting the strain was a hitherto unaccounted species of Aspergillus.

A. nanangensis was cultivated separately on jasmine rice and pearl barley for 21 days, which resulted in confluent and thick mycelial coverage of the grains. Extraction of the grains with acetone, followed by partitioning of the aqueous residue with EtOAc and defatting with hexane, provided an enriched extract of non-polar secondary metabolites. Fractionation by reversedphase preparative HPLC (Figures S1 and S2 in Supporting
Information File 1) yielded ten drimane metabolites shown in Figure 1: one trihydroxylated drimane sesquiterpenoid lactone, nanangenine $\mathrm{A}(\mathbf{1})$, four drimane lactones bearing $\mathrm{C}_{6} / \mathrm{C}_{8}$ acyl chains, nanangenines $B, C, D$ and $E(\mathbf{2}, \mathbf{4}, 5$ and $\mathbf{6})$, two acylated drimanes bearing isomeric lactones, isonanangenines $\mathrm{B}$ and $\mathrm{D}$ ( 3 and 7$)$, and three acylated drimanes, nanangenines $\mathrm{F}-\mathrm{H}(\mathbf{8}-\mathbf{1 0})$, which are putative biosynthetic intermediates. The structures of 1-10 were elucidated by detailed spectroscopic analysis, while absolute configurations were determined by single crystal X-ray diffraction analysis of selected analogues.

High-resolution positive electrospray ionisation mass spectrometry (HRESI(+)MS) analysis of nanangenine A (1) revealed an adduct ion $\left([\mathrm{M}+\mathrm{Na}]^{+} \mathrm{m} / \mathrm{z}\right.$ 305.1363) indicative of a molecular formula $\mathrm{C}_{15} \mathrm{H}_{22} \mathrm{O}_{5}$ requiring five double bond equivalents (DBE). No distinguishing absorption maxima were observed in the UV-vis spectrum, while absorptions at 3354 and $1738 \mathrm{~cm}^{-1}$ in the IR spectrum were indicative of hydroxy and carbonyl groups, respectively. The ${ }^{13} \mathrm{C}$ NMR data for $\mathbf{1}$ (Table 1 ) indicated the presence of one carbonyl carbon $\left(\delta_{C} 179.3, \mathrm{C}-11\right)$ and two olefinic carbons $\left(\delta_{\mathrm{C}} 128.2, \mathrm{C}-7\right.$ and $\left.\delta_{\mathrm{C}} 131.1, \mathrm{C}-8\right)$, accounting for two DBE and thus requiring 1 to be tricyclic. The ${ }^{1} \mathrm{H}$ and ${ }^{13} \mathrm{C}$ NMR data also revealed the presence of one hydroxylated quaternary carbon (C-9), two aliphatic quaternary carbons (C-4, C-10), two oxymethines (C-1, C-6), one aliphatic methine (C-5), one oxymethylene (C-12), two aliphatic methylenes (C-2, C-3), three methyl groups (C-13, C-14, C-15) and three hydroxy groups (1-OH, 6-OH, 9-OH). Detailed analysis of the 2D NMR data for $\mathbf{1}$ (Table S3 in Supporting Information File 1) confirmed the presence of a drimane sesquiterpenoid lactone scaffold. A search of the literature revealed $\mathbf{1}$ to be almost identical to strobilactone B, previously reported from A. ustus [29], with the only difference being hydroxylation at $\mathrm{C}-1$ in $\mathbf{1}$, instead of at C-2. Therefore, the structure of $\mathbf{1}$ was assigned as shown in Figure 1. The absolute configuration of $\mathbf{1}$ was confirmed to be $1 R, 5 S, 6 R, 9 R, 13 R$ by single crystal X-ray diffraction analysis (Table S2 and Figure S3 in Supporting Information File 1).

HRESI(+)MS analysis of nanangenine B (2) revealed an adduct ion ([M $+\mathrm{Na}]^{+} \mathrm{m} / \mathrm{z}$ 403.2096) indicative of a molecular formula $\mathrm{C}_{21} \mathrm{H}_{32} \mathrm{O}_{6}$. The NMR data for 2 (Table $\mathrm{S} 4$ in Supporting Information File 1) were very similar to those for $\mathbf{1}$, with the only significant differences being the absence of the 6-OH proton, the presence of additional signals for a $\mathrm{C}_{6}$ acyl chain, and significant deshielding of $\mathrm{H}-6$ from $\delta_{\mathrm{H}} 4.30$ to $5.47 \mathrm{ppm}$. Therefore, the structure of $\mathbf{2}$ was assigned as the 6- $O$-hexanoyl analogue of $\mathbf{1}$, as shown in Figure 1. Compound $\mathbf{2}$ was previously reported in 2014 as an unnamed metabolite from Aspergillus sp. IBWF002-96 [5], and we have assigned the trivial name nanangenine B for consistency. The absolute configuration of $\mathbf{2}$ was 


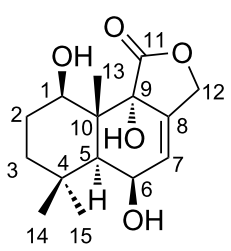

nanangenine $A(1)$<smiles>[B]CCCCCCC(=O)O[C@H]1C=C2COC(=O)[C@]2(C)[C@@H]2[C@@H](O)CCC(C)(C)[C@H]12</smiles>

nanangenine $D(5)$<smiles>CCCCCC(=O)O[C@H]1C=C(C)[C@@]2(C=O)[C@H](O)CCC(C)(C)[C@]12C</smiles>

nanangenine $F(8)$<smiles>CCCCCC(=O)O[C@H]1C=C2COC(=O)[C@@]2(O)[C@]2(C)[C@@H]1C(C)(C)CC[C@H]2O</smiles>

$B(2)$<smiles>CCCCCC(=O)O[C@H]1C=C2C(=O)OC[C@]2(O)[C@@]2(O)C(O)CCC(C)(C)[C@H]12</smiles>

isonanangenine $B(3)$

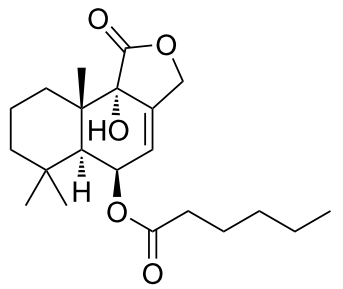

nanangenine $C(4)$

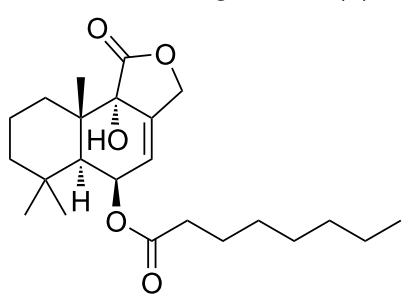

nanangenine $E(7)$

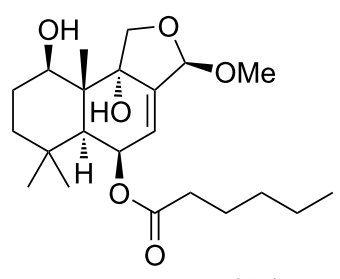

nanangenine $\mathrm{G}(\mathbf{9})$

nanangenine $\mathrm{H}$ (10)

Figure 1: Structures of nanangenines 1-10 isolated from $A$. nanangensis.

\begin{tabular}{lll} 
Table 1: NMR data for nanangenine A (1) in DMSO- $\mathrm{d}_{6}$. \\
Position & $\delta_{\mathrm{C}^{\mathrm{a}}}$ & $\delta_{\mathrm{H}}$, mult. $(\mathrm{J} \text { in Hz})^{\mathrm{b}}$ \\
\hline 1 & 69.0 & $4.12, \mathrm{dd}(8.4,7.8)$ \\
2 & 26.2 & $1.54, \mathrm{~m}$ \\
3 & 41.5 & $1.22, \mathrm{~m}$ \\
4 & 33.6 & \\
5 & 45.0 & $1.52, \mathrm{~d}(5.0)$ \\
6 & 63.3 & $4.30, \mathrm{~m}$ \\
7 & 128.2 & $5.92, \mathrm{~m}$ \\
8 & 131.1 & \\
9 & 76.1 & \\
10 & 42.4 & \\
11 & 179.3 & \\
$12 \mathrm{a}$ & 70.6 & $5.00, \mathrm{ddd}(12.2$, \\
& & $2.5,2.4)$ \\
$12 \mathrm{~b}$ & & $4.91, \mathrm{ddd}(12.2$ \\
& 12.6 & $1.3,1.2)$ \\
13 & 24.3 & $0.92, \mathrm{~s}$ \\
14 & 31.9 & $1.23, \mathrm{~s}$ \\
15 & & $1.02, \mathrm{~s}$ \\
$1-\mathrm{OH}$ & & $4.76, \mathrm{~s}$ \\
$6-\mathrm{OH}$ & & $4.81, \mathrm{br} \mathrm{d}(5.8)$ \\
$9-\mathrm{OH}$ & & $6.50, \mathrm{~s}$ \\
& &
\end{tabular}

${ }^{\text {aAcquired at }} 125 \mathrm{MHz}$; bacquired at $500 \mathrm{MHz}$. assigned based on single crystal X-ray diffraction analysis of a 9-O-(4-bromobenzoyl) derivative (2b; Table S2 and Figure S4 in Supporting Information File 1).

HRESI(+)MS analysis of isonanangenine B (3) revealed an adduct ion $\left([\mathrm{M}+\mathrm{Na}]^{+} \mathrm{m} / \mathrm{z}\right.$ 403.2094) indicative of a molecular formula $\mathrm{C}_{21} \mathrm{H}_{32} \mathrm{O}_{6}$, which is isomeric with 2. Comparison of the NMR data for 3 (Table S5 in Supporting Information File 1) with those for 2 revealed the only difference to be the position of the lactone carbonyl group, which was determined to be at $\mathrm{C}-12$ instead of $\mathrm{C}-11$ based on key HBMC correlations from H-7 to C-12 and 9-OH to C-11. Therefore, the structure of 3 was assigned as shown in Figure 1. Compound 3 was previously reported in 2013 as an unnamed metabolite (code number SF002-96-1) from Aspergillus sp. IBWF002-96 [4], and we have assigned the trivial name isonanangenine B for consistency. The absolute configuration of $\mathbf{3}$ was assigned based on single crystal X-ray diffraction analysis of a 1-O-(4-bromobenzoyl) derivative (3b; Table S2 and Figure S5 in Supporting Information File 1).

HRESI(+)MS analysis of nanangenine $\mathrm{C}(4)$ revealed an adduct ion ([M $+\mathrm{Na}]^{+} \mathrm{m} / \mathrm{z}$ 387.2147) indicative of a molecular formula $\mathrm{C}_{21} \mathrm{H}_{32} \mathrm{O}_{5}$, which has one fewer oxygen atom than $\mathbf{2}$ and $\mathbf{3}$. 
Comparison of the NMR data for 4 (Table S6 in Supporting Information File 1) with those for 2 revealed the only significant differences to be the absence of the $\mathrm{H}-1$ and $1-\mathrm{OH}$ protons and the presence of an additional methylene group $\left(\mathrm{H}_{2}-1\right)$. Therefore, the structure of $\mathbf{4}$ was assigned to be the 1-deoxy analogue of 2, as shown in Figure 1. Compound $\mathbf{4}$ was previously reported in 2014 as an unnamed metabolite from Aspergillus sp. IBWF002-96 [5], and we have assigned the trivial name nanangenine $\mathrm{C}$ for consistency. The absolute configuration of $\mathbf{4}$ was assigned based on single crystal X-ray diffraction analysis (Table S2 and Figure S6 in Supporting Information File 1).

Nanangenine D (5), isonanangenine D (6) and nanangenine E (7) had virtually identical spectroscopic data to $\mathbf{2}, \mathbf{3}$ and $\mathbf{4}$, re- spectively, with the only significant differences being the presence of two additional resonances in the aliphatic region of the ${ }^{13} \mathrm{C}$ NMR spectra (Table 2) and an increase in area of four protons in the methylene envelopes of the ${ }^{1} \mathrm{H}$ NMR spectra. Therefore, the structures of 5-7 were assigned to be the $\mathrm{C}_{8}$ homologs of 2-4, respectively, as shown in Figure 1. The absolute configurations of 5-7 were assigned to be the same as 2-4 based on their similar NMR data and optical rotations.

HRESI(+)MS analysis of nanangenine $\mathrm{F}(\mathbf{8})$ revealed a protonated molecule $\left([\mathrm{M}+\mathrm{H}]^{+} \mathrm{m} / \mathrm{z} 367.2483\right)$ indicative of a molecular formula $\mathrm{C}_{21} \mathrm{H}_{34} \mathrm{O}_{5}$, requiring one fewer DBE than 2 . Indeed, the NMR data for $\mathbf{8}$ (Table 3 ) were very similar to those for 2 , with the main differences being the absence of signals for the lactone carbonyl and oxymethylene group, and the presence

\begin{tabular}{|c|c|c|c|c|c|c|}
\hline \multirow[t]{2}{*}{ Position } & \multicolumn{2}{|r|}{ Nanangenine D (5) } & \multicolumn{2}{|c|}{ Isonanangenine D (6) } & \multicolumn{2}{|r|}{ Nanangenine $\mathrm{E}(\mathbf{7})$} \\
\hline & $\delta_{C}^{a}$ & $\delta_{\mathrm{H}}$, mult. $(J \text { in } \mathrm{Hz})^{\mathrm{b}}$ & $\delta_{C}^{a}$ & $\delta_{\mathrm{H}}$, mult. $(J \text { in } \mathrm{Hz})^{\mathrm{b}}$ & $\delta_{C}{ }^{a}$ & $\delta_{\mathrm{H}}$, mult. $(J \text { in } \mathrm{Hz})^{\mathrm{b}}$ \\
\hline $1 a$ & 68.7 & 4.17, ddd $(10.9,5.9,0.9)$ & 68.6 & 3.95, ddd $(12.0,5.9,3.9)$ & 29.4 & 1.95, ddd $(15.0,13.5,4.3)$ \\
\hline $1 b$ & & & & & & $1.81, \mathrm{dm}(13.5)$ \\
\hline $2 a$ & 25.9 & $1.57, \mathrm{~m}$ & 27.2 & $1.53, \mathrm{~m}$ & 17.4 & $1.59, \mathrm{~m}$ \\
\hline $2 b$ & & & & & & $1.47, \mathrm{~m}$ \\
\hline $3 a$ & 41.3 & $1.28, \mathrm{~m}$ & 41.7 & 1.31, ddd $(13.3,3.5,3.5)$ & 44.3 & $1.33, \mathrm{dm}(13.0)$ \\
\hline $3 b$ & & & & $1.23, \mathrm{~m}$ & & $1.19, \mathrm{~m}$ \\
\hline 4 & 33.1 & & 32.9 & & 33.3 & \\
\hline 5 & 43.8 & $1.87, \mathrm{~d}(4.9)$ & 44.1 & $1.99, d(5.2)$ & 44.0 & $1.97, d(4.9)$ \\
\hline 6 & 66.0 & $5.46, \mathrm{~m}$ & 66.0 & $5.59, \mathrm{dd}(5.1,3.9)$ & 66.0 & $5.47, \mathrm{~m}$ \\
\hline 7 & 121.9 & $5.88, \mathrm{~m}$ & 131.6 & $6.45, d(3.9)$ & 121.3 & $5.77, \mathrm{~m}$ \\
\hline 8 & 135.5 & & 133.2 & & 136.5 & \\
\hline 9 & 75.6 & & 75.0 & & 73.1 & \\
\hline 10 & 42.4 & & 43.2 & & 37.2 & \\
\hline $11 a$ & 178.4 & & 76.4 & $4.41, \mathrm{dd}(10.2,0.5)$ & 174.3 & \\
\hline $11 b$ & & & & 4.19, br d (10.2) & & \\
\hline $12 a$ & 70.3 & 5.03, ddd $(12.8,4.8,2.5)$ & 168.6 & & 68.2 & 4.87, ddd $(12.8,2.5,2.5)$ \\
\hline $12 b$ & & 4.94, ddd $(12.8,1.7,1.2)$ & & & & 4.74, ddd $(12.8,1.2,1.2)$ \\
\hline 13 & 12.2 & $0.94, \mathrm{~s}$ & 12.3 & $0.94, \mathrm{~s}$ & 18.1 & $0.99, \mathrm{~s}$ \\
\hline 14 & 24.0 & $1.06, \mathrm{~s}$ & 24.2 & $1.08, \mathrm{~s}$ & 24.2 & $1.08, \mathrm{~s}$ \\
\hline 15 & 31.5 & $0.90, \mathrm{~s}$ & 31.9 & $0.91, \mathrm{~s}$ & 32.1 & $0.91, \mathrm{~s}$ \\
\hline $1^{\prime}$ & 172.2 & & 172.2 & & 172.2 & \\
\hline 2 'a & 34.0 & $2.33, \mathrm{~m}$ & 33.9 & 2.36, m & 34.0 & $2.32, \mathrm{~m}$ \\
\hline $2 ' b$ & & $2.27, \mathrm{~m}$ & & $2.27, \mathrm{~m}$ & & $2.25, \mathrm{~m}$ \\
\hline $3^{\prime}$ & 24.2 & $1.53, \mathrm{~m}$ & 24.2 & $1.53, \mathrm{~m}$ & 24.2 & $1.52, \mathrm{~m}$ \\
\hline $4^{\prime}$ & 28.2 & $1.24, \mathrm{~m}$ & 28.2 & $1.23, \mathrm{~m}$ & 28.3 & $1.24, \mathrm{~m}$ \\
\hline $5^{\prime}$ & 28.3 & $1.24, \mathrm{~m}$ & 28.2 & $1.23, \mathrm{~m}$ & 28.2 & $1.24, \mathrm{~m}$ \\
\hline $6^{\prime}$ & 31.0 & $1.22, \mathrm{~m}$ & 31.0 & $1.21, \mathrm{~m}$ & 31.0 & $1.21, \mathrm{~m}$ \\
\hline $7^{\prime}$ & 21.9 & $1.24, \mathrm{~m}$ & 21.9 & $1.23, \mathrm{~m}$ & 21.9 & $1.24, \mathrm{~m}$ \\
\hline $8^{\prime}$ & 13.9 & $0.84, \mathrm{t}(7.9)$ & 13.9 & $0.83, \mathrm{t}(7.2)$ & 13.9 & $0.84, \mathrm{t}(7.2)$ \\
\hline $1-\mathrm{OH}$ & & $4.71, d(0.9)$ & & $4.62, d(5.1)$ & & - \\
\hline $9-\mathrm{OH}$ & & $6.77 \mathrm{~s}$ & & $5.61 \mathrm{br} \mathrm{s}$ & & $6.24 \mathrm{~s}$ \\
\hline
\end{tabular}

aAcquired at $150 \mathrm{MHz}$; bacquired at $600 \mathrm{MHz}$. 


\begin{tabular}{|c|c|c|c|c|c|c|}
\hline \multirow[t]{2}{*}{ Position } & \multicolumn{2}{|r|}{ Nanangenine F (8) } & \multicolumn{2}{|r|}{ Nanangenine G (9) } & \multicolumn{2}{|r|}{ Nanangenine $\mathrm{H}(\mathbf{1 0})$} \\
\hline & $\delta_{C}^{a}$ & $\delta_{\mathrm{H}}$, mult. $(J \text { in } \mathrm{Hz})^{\mathrm{b}}$ & $\delta_{C}{ }^{c}$ & $\delta_{\mathrm{H}}$, mult. $(J \text { in } \mathrm{Hz})^{\mathrm{d}}$ & $\delta_{C}{ }^{a}$ & $\delta_{\mathrm{H}}$, mult. $(J \text { in } \mathrm{Hz})^{\mathrm{b}}$ \\
\hline 1 & 68.5 & 3.88, ddd $(11.9,5.8,5.8)$ & 69.1 & $3.93 \mathrm{dd}(11.2,4.3)$ & 68.4 & 3.93, ddd $(11.8,5.4,5.0)$ \\
\hline $2 a$ & 27.3 & $1.51, \mathrm{~m}$ & 28.3 & $1.56, \mathrm{~m}$ & 27.5 & $1.53, \mathrm{~m}$ \\
\hline $2 b$ & & $1.47, \mathrm{~m}$ & & & & $1.48, \mathrm{~m}$ \\
\hline $3 a$ & 41.6 & $1.26, \mathrm{~m}$ & 41.6 & $1.23, \mathrm{~m}$ & 41.9 & $1.27, \mathrm{~m}$ \\
\hline $3 b$ & & $1.21, \mathrm{~m}$ & & & & $1.22, \mathrm{~m}$ \\
\hline 4 & 32.8 & & 33.5 & & 32.8 & \\
\hline 5 & 43.5 & $1.84, d(4.7)$ & 44.9 & $1.83, \mathrm{~d}(4.4)$ & 44.3 & $1.95, \mathrm{~d}(4.0)$ \\
\hline 6 & 66.5 & $5.37, \mathrm{~m}$ & 67.0 & $5.41, \mathrm{~m}$ & 67.1 & 5.46, ddd $(5.0,3.9,1.4)$ \\
\hline 7 & 124.0 & $5.53, \mathrm{dq}(5.1,1.5)$ & 121.4 & 5.78, br d (5.3) & 120.3 & 5.57, dd $(3.9,1.4)$ \\
\hline 8 & 137.2 & & 144.1 & & 145.0 & \\
\hline 9 & 80.1 & & 75.6 & & 78.3 & \\
\hline 10 & 47.0 & & 45.9 & & 43.5 & \\
\hline $11 a$ & 203.3 & 9.49, br s & 62.2 & $3.73, \mathrm{~m}$ & 74.5 & $3.84, d(9.7)$ \\
\hline $11 b$ & & & & $3.67, \mathrm{~m}$ & & $3.76, d(9.7)$ \\
\hline $12 a$ & 19.5 & $1.51, \mathrm{dd},(1.3,1.3)$ & 61.0 & $4.05, \mathrm{~m}$ & 101.9 & $5.31, \mathrm{t}(1.4)$ \\
\hline $12 b$ & & & & 4.02, m & & \\
\hline 13 & 11.5 & $1.06, \mathrm{~s}$ & 12.5 & $1.06, \mathrm{~s}$ & 11.7 & $0.92, \mathrm{~s}$ \\
\hline 14 & 24.3 & $1.05, \mathrm{~s}$ & 24.4 & $1.03, \mathrm{~s}$ & 24.3 & $1.08, \mathrm{~s}$ \\
\hline 15 & 31.8 & $0.89, \mathrm{~s}$ & 32.4 & $0.87, \mathrm{br} \mathrm{s}$ & 32.1 & $0.89, \mathrm{~s}$ \\
\hline $1^{\prime}$ & 172.3 & & 172.7 & & 172.3 & \\
\hline $2^{\prime} a$ & 34.1 & $2.30, \mathrm{~m}$ & 34.5 & $2.24, \mathrm{~m}$ & 34.1 & $2.32, \mathrm{~m}$ \\
\hline $2 ' b$ & & $2.23, \mathrm{~m}$ & & $2.21, \mathrm{~m}$ & & $2.23, \mathrm{~m}$ \\
\hline $3^{\prime}$ & 23.9 & $1.53, \mathrm{~m}$ & 24.2 & $1.53, \mathrm{~m}$ & 24.0 & $1.52, \mathrm{~m}$ \\
\hline $4^{\prime}$ & 30.6 & $1.25, \mathrm{~m}$ & 30.9 & $1.25, \mathrm{~m}$ & 30.5 & $1.24, \mathrm{~m}$ \\
\hline $5^{\prime}$ & 21.7 & $1.26, \mathrm{~m}$ & 22.0 & $1.26, \mathrm{~m}$ & 21.7 & $1.25, \mathrm{~m}$ \\
\hline $6^{\prime}$ & 13.7 & $0.84, \mathrm{t}(7.0)$ & 13.9 & $0.83, \mathrm{t}(7.1)$ & 13.9 & $0.84, \mathrm{t}(7.1)$ \\
\hline 12-OMe & - & - & - & - & 54.1 & $3.26, \mathrm{~s}$ \\
\hline $1-\mathrm{OH}$ & & $4.74, \mathrm{~d},(5.7)$ & & $5.07, \mathrm{br} \mathrm{s}$ & & $4.37, \mathrm{~d}(5.4)$ \\
\hline $9-\mathrm{OH}$ & & $5.46, \mathrm{~s}$ & & 4.41, br s & & $4.93, \mathrm{~s}$ \\
\hline $11-\mathrm{OH}$ & & - & & $5.27, \mathrm{br} \mathrm{s}$ & & - \\
\hline $12-\mathrm{OH}$ & & - & & $4.88, \mathrm{br} \mathrm{s}$ & & - \\
\hline
\end{tabular}

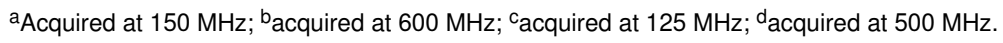

of signals for putative aldehyde $\left(\delta_{\mathrm{C}} 203.3 ; \delta_{\mathrm{H}} 9.49\right.$, s) and olefinic methyl $\left(\delta_{\mathrm{C}} 19.5 ; \delta_{\mathrm{H}} 1.51\right.$, dd) groups. Key HMBC correlations (Table S10 in Supporting Information File 1) from 9-OH to C-11 and from $\mathrm{H}-11$ to $\mathrm{C}-9$ positioned the aldehyde on C-9, while HMBC correlations from $\mathrm{H}-7$ to $\mathrm{C}-12$ and from $\mathrm{H}_{3}-12$ to $\mathrm{C}-9$ positioned the methyl on C- 8 . Therefore, the structure of $\mathbf{8}$ was assigned as the seco analogue of $\mathbf{2}$, as shown in Figure 1. The absolute configuration of $\mathbf{8}$ was assigned to be the same as $\mathbf{2}$ based on their similar NMR data and optical rotations, supported by key ROESY correlations between $\mathrm{H}_{3}-13$ and H-11, and between H-5 and 9-OH (Table S10 in Supporting Information File 1).

HRESI(+)MS analysis of nanangenine $\mathrm{G}(\mathbf{9})$ revealed an adduct ion ([M $+\mathrm{Na}]^{+} \mathrm{m} / \mathrm{z}$ 407.2406) indicative of a molecular formula
$\mathrm{C}_{21} \mathrm{H}_{36} \mathrm{O}_{6}$. The NMR data for 9 (Table 3) were very similar to those for 2 , with the main differences being the absence of a signal for the lactone carbonyl group and the presence of additional signals for an additional oxymethylene $\left(\delta_{\mathrm{C}} 62.2 ; \delta_{\mathrm{H}} 3.73 /\right.$ $3.67, \mathrm{~m})$ and two additional hydroxy groups $\left(\delta_{\mathrm{H}} 5.27\right.$, br $\mathrm{s}$ and 4.88 , br s). The ${ }^{1} \mathrm{H}$ NMR signals for oxymethylene $\mathrm{H}_{2}-12$ were also shifted upfield by $\approx 1 \mathrm{ppm}$ compared to those in 2 , suggesting the pendant oxygen atom was no longer attached to a carbonyl carbon. A detailed analysis of the 2D NMR data for 9 (Table S11 in Supporting Information File 1) confirmed the structure to be the seco analogue of $\mathbf{2}$, as shown in Figure 1. The absolute configuration of 9 was then confirmed to be the same as $\mathbf{2}$ by single crystal X-ray diffraction analysis (Table S2 and Figure S7 in Supporting Information File 1). 
HRESI(+)MS analysis of nanangenine $\mathrm{H}(\mathbf{1 0})$ revealed a protonated dehydration product $\left(\left[\mathrm{M}-\mathrm{H}_{2} \mathrm{O}+\mathrm{H}\right]^{+} m / z\right.$ 379.2473) indicative of a molecular formula $\mathrm{C}_{22} \mathrm{H}_{36} \mathrm{O}_{6}$. The NMR data for 10 (Table 3 ) were very similar to those for $\mathbf{3}$, with the main differences being the absence of a signal for the lactone carbon$\mathrm{yl}$ group and the presence of additional signals for acetal $\left(\delta_{\mathrm{C}} 101.9 ; \delta_{\mathrm{H}} 5.31, \mathrm{t}\right)$ and methoxy $\left(\delta_{\mathrm{C}} 54.1 ; \delta_{\mathrm{H}} 3.26\right.$, s) groups. Key HMBC correlations (Table S12 in Supporting Information File 1) from $\mathrm{H}-7$ to $\mathrm{C}-12$ and from $12-\mathrm{OMe}$ to $\mathrm{C}-12$ positioned the methoxy group and acetal proton on $\mathrm{C}-12$. Thus, the structure of $\mathbf{1 0}$ was assigned as shown in Figure 1. The configuration of 10 at C-12 was determined to be $12 R$ based on a key ROESY correlation between H-12 and 9-OH (Table S12, Supporting Information File 1), with the absolute configuration of the remainder of the molecule assumed to be the same as $\mathbf{3}$ based on their similar NMR data and optical rotations.

\section{Bioassays}

The nanangenines were assayed for in vitro activity against four mammalian cell lines, two bacteria, one fungus and one plant (Table 4). Compound 1 was inactive up to $100 \mu \mathrm{g} \mathrm{mL}^{-1}$ in all of the assays performed, suggesting acylation at 6-OH is important for biological activity. Compounds $\mathbf{4}, \mathbf{5}$ and $\mathbf{7}$ showed moderate antibacterial activity against $B$. subtilis, with weaker activity observed for $2,3,6$ and 8 . Compounds $2,5,8,9$ and 10 exhibited low levels of cytotoxicity against the four mammalian cell lines tested, while $\mathbf{3}, \mathbf{6}$ and $\mathbf{7}$ were considerably more cytotoxic. Notably, 4 showed strong activity against the mouse myeloma NS-1 cell line, but no activity against the three human cell lines. None of the compounds tested showed any activity up to $100 \mu \mathrm{g} \mathrm{mL}^{-1}$ against the Gram-negative bacterium Escherichia coli (ATCC 25922), the fungus Candida albicans (ATCC 10231) or the plant Eragrostis tef (teff).

\section{Proposed biosynthesis and gene cluster}

The biosynthesis of drimane-type sesquiterpenoids from farnesyl diphosphate is proposed to proceed via the protonationinitiated mechanism (class II terpene synthases) [24], which is distinct from the ionisation-initiated mechanism (class I) terpene synthases, where a carbocation is generated by the release of a diphosphate group [30]. Therefore, the drimane synthase is likely to be different from the commonly observed sesquiterpene synthase, which belongs to the class I terpene synthases. Recently, the drimane synthase AstC involved in biosynthesis of the astellolides was identified and shown to be a novel member of the terpene synthase family, showing similarity to haloacid dehalogenase (HAD)-like hydrolases [21]. Thus, we suspected that a related enzyme may be involved in the biosynthesis of the nanangenines, and used the amino acid sequence of AstC to probe the A. nanangensis genome. We also hypothesised that the acyl side chains present in the (iso)nanangenines could be derived either from a fatty acid synthase (FAS) or polyketide synthase (PKS). For example, in aflatoxin biosynthesis, the hexanoyl started unit is supplied by a FAS [31], while in the meroterpenoid fumagillin biosynthesis, the unsaturated acyl chain is synthesised by a PKS [32].

The A. nanangensis genome was sequenced and a draft assembly of the genome was generated. A local BLASTp search of the A. nanangensis genome using the drimane synthase AstC as query returned a hit on scaffold 3, FE257_006542, which was immediately flanked by a highlyreducing PKS (FE257_006541) and a FAD-binding oxidoreductase (FE257_006543). AstC, though annotated as a HADlike hydrolase and having low sequence homology to other characterised terpene synthases, contains sequence motifs conserved across both class I (DDxxD/E) and class II (DxDD,

\begin{tabular}{|c|c|c|c|c|c|}
\hline \multirow[t]{2}{*}{ Compound } & \multicolumn{5}{|c|}{ 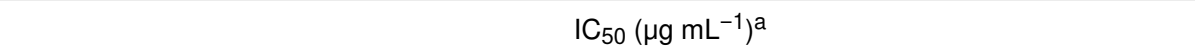 } \\
\hline & $B s^{b}$ & $\mathrm{NS}-1^{\mathrm{C}}$ & DU-145 & MCF- $7^{e}$ & $\mathrm{Nfff}^{f}$ \\
\hline 1 & $>100$ & $>100$ & $>100$ & $>100$ & $>100$ \\
\hline 2 & $62 \pm 2$ & $38 \pm 1.5$ & $>100$ & $>100$ & $>100$ \\
\hline 3 & $56 \pm 6$ & $0.16 \pm 0.01$ & $0.9 \pm 0.2$ & $0.19 \pm 0.05$ & $0.9 \pm 0.1$ \\
\hline 4 & $5.7 \pm 0.1$ & $4.1 \pm 0.1$ & $>100$ & $>100$ & $>100$ \\
\hline 5 & $9.4 \pm 0.4$ & $19 \pm 2$ & $37 \pm 2$ & $22 \pm 1$ & $37 \pm 2$ \\
\hline 6 & $4 \%^{g}$ & $1.0 \pm 0.1$ & $32 \pm 3$ & $3.6 \pm 0.4$ & $2.1 \pm 0.3$ \\
\hline 7 & $2.3 \pm 0.3$ & $2.4 \pm 0.1$ & $15 \pm 1$ & $9.4 \pm 0.7$ & $6.8 \pm 0.6$ \\
\hline 8 & $78 \pm 2$ & $49 \pm 2$ & $95 \pm 3$ & $49 \pm 1$ & $84 \pm 2$ \\
\hline 9 & $>100$ & $47 \pm 2$ & $>100$ & $>100$ & $>100$ \\
\hline 10 & $>100$ & $10 \pm 2$ & $7 \% 9$ & $62 \pm 2$ & $60 \pm 1$ \\
\hline control & $0.4^{\mathrm{h}}$ & $0.02^{i}$ & $18^{\mathrm{i}}$ & $2^{i}$ & $0.2^{\mathrm{i}}$ \\
\hline
\end{tabular}

${ }^{a}$ Experiments were conducted in triplicate. $\mathrm{IC}_{50}$ values are mean \pm standard error; ${ }^{\mathrm{b}}$ Bacillus subtilis (ATCC 6633 ); ${ }^{\mathrm{C}}$ mouse myeloma NS-1 cell line (ATCC TIB-18); dhuman prostate cancer DU-145 cell line (ATCC HTB-81); ${ }^{e} H u m a n$ breast adenocarcinoma MCF-7 cell line (ATCC HTB-22); ${ }^{f} H u m a n$ fibroblast NFF cell line (ATCC PCS-201); 9incomplete dose response, \% inhibition reached at $100 \mu \mathrm{gL}^{-1}$; ${ }_{\text {tetracycline; }}$ 'staurosporine. 
QW) terpene synthases [33-35]. Specifically, AstC contains a DxDTT motif [21], which is a variant of the DxDD motif known to be involved in class II-type protonation-initiated terpene cyclisation [36]. Importantly, the DDxxD motif in AstC contains a substitution of the second Asp for Asn, leading to a loss of ionisation-activated cyclisation activity. Two other HAD-like hydrolases, AstI and AstK, with the class I (DDxxD/ E) motif, are therefore required to catalyse other dephosphorylation steps. Despite overall low sequence homology, alignment with the amino acid sequences of AstC, AstI, AstK and related homologs confirmed the presence of both conserved class I and class II motifs in FE257_006542 (Figure S50 and Table S15 in Supporting Information File 1).

Drimane sesquiterpenoids are produced by several species across the Aspergillus genus, with compounds possessing acyl side chains observed specifically in section Usti, such as A. ustus [37,38], A. insuetus [39], A. pseudodeflectus [40] and other unnamed species [17]. A. calidoustus, another member of section Usti, also produces drimane sesquiterpenoids, though no compounds with acyl side chains have yet been reported [41]. Notably, the acyl chains that these compounds possess are unsaturated polyenes, while the acyl chains of the nanangenines are fully saturated. As noted earlier, 2-4 were previously reported as unnamed metabolites from Aspergillus sp. IBWF002-96 [4,5], which has an internal transcribed spacer (ITS) sequence that shares $100 \%$ identity with an uncultured soil sample (NCBI accession GQ921753.1) and 97\% identity with $A$. janus (NCBI accession EU021598). The ITS sequence of $A$. nanangensis (deposited on NCBI, accession MK979278) also shares $100 \%$ sequence identity with the uncultured soil sample, and 97\% identity with A. janus (Figure S51 in Supporting Information File 1). No public sequence could be found for IBWF002-96. Interestingly, the uncultured soil sample was also isolated from soil near the town of Nanango in Queensland, Australia, as part of a survey of soil fungal communities in monoculture Araucaria cunninghamii plantations, though it remained unidentified [42]. While we cannot conclusively determine each strain to be A. nanangensis, the ITS sequences of all three strains are identical and they clearly clade in section Jani (Figure S48 in Supporting Information File 1).

A comparative genomics survey of all publicly available genomes on NCBI and the Joint Genome Institute (JGI) genome portal of known drimane sesquiterpenoid producers was undertaken (Figure S49 in Supporting Information File 1). Homologous gene clusters were observed in all drimane sesquiterpenoid-producing members of section Usti: A. ustus CBS 3.3904, A. calidoustus CBS 12160 and A. insuetus CBS 107.25 (Figure 2). A homologous cluster was also found in A. pseudodeflectus CBS 756.74, though it is located on a truncated assembly scaffold. In total, six genes are conserved across these species: the HR-PKS (FE257_006541), HAD-like terpene synthase (FE257_006542) and FAD-binding oxidoreductase (FE257_006543), as well as a cytochrome P450 (FE257_006544), an alpha/beta hydrolase (FE257_006545) and a short-chain dehydrogenase (FE257_006546). Notably, no homologous clusters were identified in other members of section Jani (A. brevijanus and A. janus) that have not been reported to produce such drimane sesquiterpenoids. A phylogenetic tree of all AstC homologs identified in the genomes of all known drimane sesquiterpenoid producers was constructed, in which

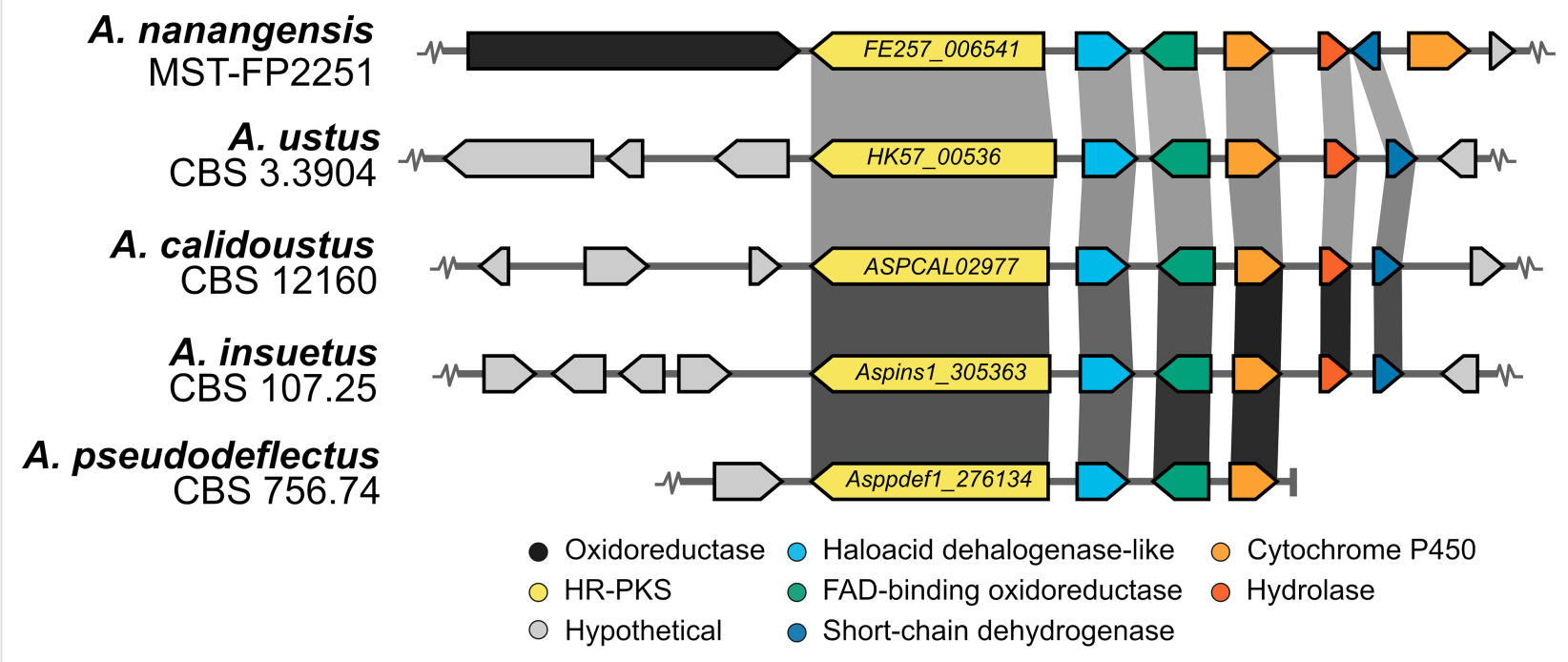

Figure 2: Putative nanangenine biosynthetic gene cluster in A. nanangensis MST-FP2251 and homologs identified in other drimane sesquiterpenoidproducing species of Aspergillus section Usti. Gene models are drawn to scale; shaded boxes that link gene models represent amino acid identity (0\% transparent; $100 \%$ black). 
the putative HAD-like terpene synthases (drimane synthases) from the section Usti form a distinct clade, separate from the AstC type (Figure S52 in Supporting Information File 1). The analysis above, and the discovery of other homologous gene clusters in Aspergillus spp. that are known to produce acyl drimane sesquiterpenoids, support the identification of this as the putative biosynthetic gene cluster for nanangenines.

Based on the analyses above, a biosynthetic pathway to the nanangenines was proposed (Figure 3). Unlike the ast cluster, where there are multiple HAD-like enzymes encoded (one terpene synthase and two phosphatases), the putative nanangenine cluster only encodes one such enzyme, FE257_006542. However, given that FE257_006542 contains both class I $(\mathrm{DDxxD} / \mathrm{E})$ and class II (DxDD, QW) terpene synthases, we propose that FE257_006542 is responsible for both the cyclisation into drimanyl diphosphate and the hydrolysis of the diphosphate into drim-8-ene-11-ol. We propose the next step in the pathway is hydroxylation at C-6 or C-9, as hydroxylation at both sites is common to all of the (iso)nanangenines. The 9-hydroxylation also results in migration of the double bond on the decalin to $\Delta^{7,8}$. The two hydroxylations could be catalysed by the FAD-dependent oxidoreductase or one of the cytochrome P450 oxygenases. From this point, the pathway branches out to the different (iso)nananagenines via combinations of hydroxylation at C-1 (or not) and one or multiple oxidations at C-11 and C-12. The oxidations of methyl to alcohol and alcohol to aldehyde could be catalysed by one of the two P450 oxygenases, or the short-chain dehydrogenase could oxidise the alcohol (at C-11 or C-12) to an aldehyde. Depending on whether C-11 or C-12 formed an aldehyde, further oxidation of the aldehyde to a carboxylic acid and condensation with the $\gamma-\mathrm{OH}$ group would afford the butyrolactone ring in nanagenines A-E and isonanagenines $\mathrm{B} / \mathrm{D}$, respectively. The C-6 and C-8 lipid chain is likely produced by the HR-PKS encoded by gene FE257_006541, while the acylation could be attributed to the enzyme encoded by FE257_006545, which contains the conserved domain of the alpha/beta-hydrolase fold superfamily (which includes thioesterases and acyltransferases, e.g., LovD [43]). Therefore, the identified putative gene cluster encodes all the genes predicted to be required for biosynthesis of the (iso)nanangenines. We are currently in the process of verifying

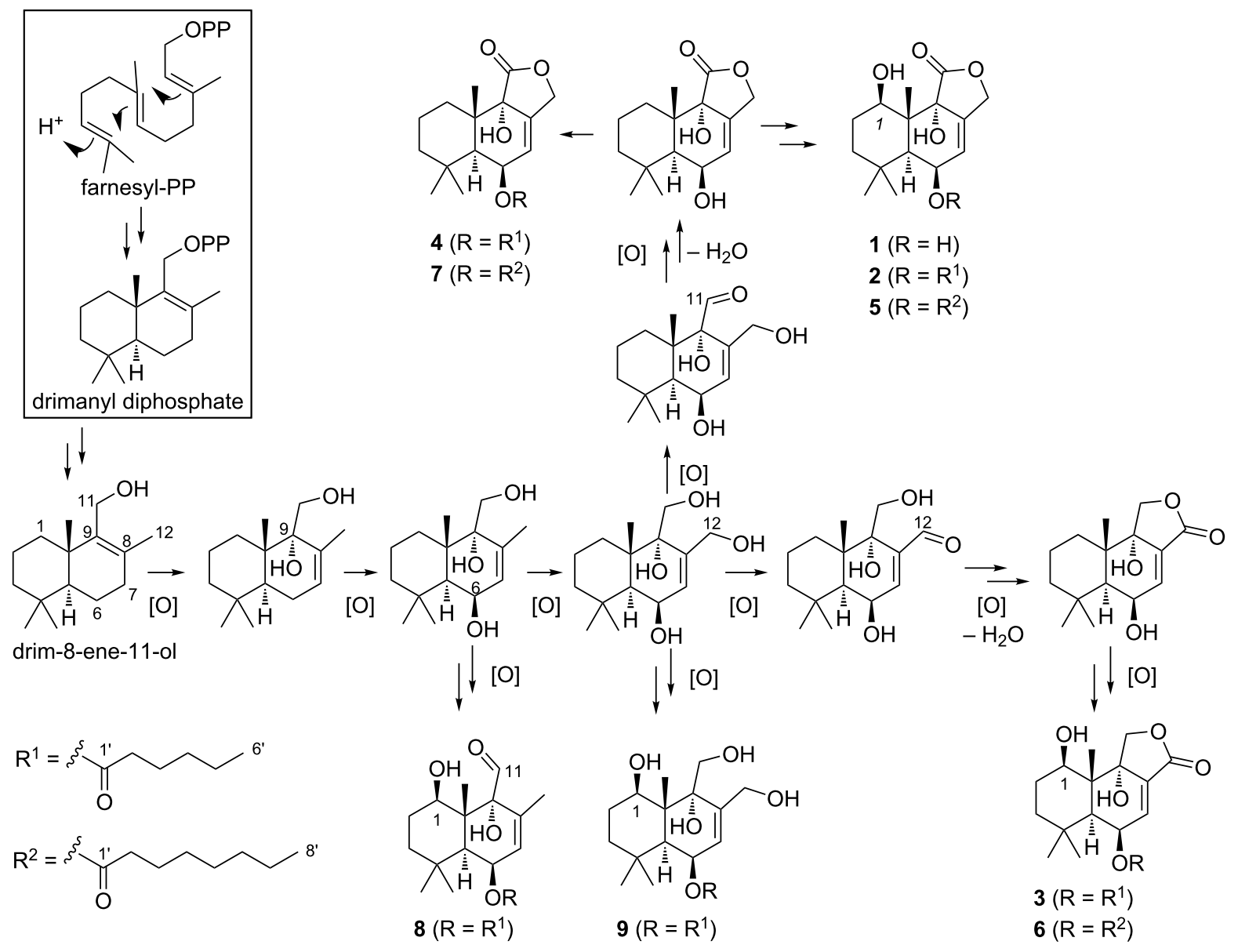

Figure 3: Putative biosynthetic pathway to the nanangenines. 
the putative biosynthetic gene cluster by genetic deletion and heterologous expression.

\section{Conclusion}

Our investigations into unique Australian microbial biodiversity have led to discovery of a family of drimane sesquiterpenoids, the nanangenines, which serve as key chemotaxonomic markers for the novel fungal species, A. nanangensis. Although related drimane sesquiterpenoid lactones have been found in several Aspergilli, drimane sesquiterpenoids with saturated fatty acyl chains have only been reported in one Aspergillus strain (IBWF002-96), which appears to share an identical ITS sequence with A. nanangensis [4,5]. Interestingly, drimane sesquiterpenoids are not produced uniformly within the Aspergillus genus, instead clustering within the sections Usti, Circumdati and Flavi (Figure S49 in Supporting Information File 1). The drimane sesquiterpenoids are not among the dominant metabolite classes commonly used for Aspergillus chemotaxonomy, but have been used for chemotyping of Aspergilli in the section Usti [17]. Here, we showed for the first time that an Aspergillus species from the section Jani produces such drimane sesquiterpenoids and has a secondary metabolite repertoire that is distinct from close members in the section Jani. Comparative analysis identified a group of putative homologous acyl drimane sesquiterpenoid biosynthetic gene clusters that are shared among A. nanangensis and Aspergilli in the section Usti. Interestingly, the putative nanangenine biosynthetic gene cluster, and those homologs in Aspergillus section Usti, only shared low homology to the astellolide biosynthetic gene cluster identified in A. oryzae. Further investigation by genetic knockout or heterologous expression is required to confirm the identity of the putative nanangenine biosynthetic gene cluster. Over the range of biological assays performed, isonanangenines $\mathbf{3}$ and $\mathbf{6}$, in particular, exhibited strong activity against human and murine tumour cell lines. This suggests that the regioisomeric lactone moiety could play an important role in the observed cytotoxicity. Interestingly, 3 (SF002-96-1 [4]) was previously shown to inhibit survivin, which is a member of the inhibitor of apoptosis (IAP) family and a potential cancer target. Further structure-activity relationship studies are required to fully characterise this potential anticancer pharmacophore. This study again demonstrates how taxonomy-guided exploration of fungi is a highly effective strategy for identifying novel bioactive metabolites.

\section{Experimental}

\section{General experimental details}

Optical rotations were acquired in $\mathrm{MeOH}$ on a Perkin-Elmer Model 341 polarimeter in a $50 \times 5 \mathrm{~mm}$ cell or on a Jasco $\mathrm{P}-1010$ polarimeter in a $100 \times 3.5 \mathrm{~mm}$ cell. UV-vis spectra were acquired in $\mathrm{MeCN}$ on a Varian Cary 4000 spectropho- tometer or a Jasco V-760 spectrophotometer in a $10 \times 10 \mathrm{~mm}$ quartz cuvette. Analytical HPLC was performed on a gradient Shimadzu VP HPLC system equipped with a Shimadzu SPDM10A VP diode array detector and an LC-10AT VP gradient chromatograph. Preparative HPLC was performed on a gradient Shimadzu HPLC system comprising two LC-8A preparative liquid pumps with static mixer, SPD-M10AVP diode array detector and SCL-10AVP system controller with standard Rheodyne injection port. The columns used in the purification of the metabolites were selected from either a Hypersil $\mathrm{C}_{18}$ column $\left(50 \times 100 \mathrm{~mm}, 5 \mu \mathrm{m}\right.$; Grace Discovery), a Vydac $\mathrm{C}_{18}$ column $(50 \times 100 \mathrm{~mm}, 5 \mu \mathrm{m}$; Grace Discovery $)$, a Zorbax SB-C ${ }_{18}$ column $(50 \times 150 \mathrm{~mm}, 5 \mu \mathrm{m}$; Agilent $)$ or an Alltima $\mathrm{C}_{18}$ column $(22 \times 250 \mathrm{~mm}, 5 \mu \mathrm{m}$, Grace Discovery $)$, eluted isocratically with acetonitrile/water mixtures with or without $0.01 \%$ TFA modifier, as described for each separation. LCMS was performed on an Agilent 1260 Infinity series HPLC equipped with an Agilent 6130 Infinity series single quadrupole mass detector in both positive and negative ion modes. High-resolution electrospray ionisation mass spectra (HRESIMS) were obtained on a Bruker Apex Qe 7T Fourier Transform Ion Cyclotron Resonance mass spectrometer equipped with an Apollo II ESI/MALDI Dual source or a Q Exactive Plus hybrid quadrupole-Orbitrap mass spectrometer (Thermo Fisher Scientific, Bremen, Germany) by direct infusion. NMR data were recorded in DMSO- $d_{6}$ on either a Bruker Avance III 500 or a Bruker Avance II DRX-600K spectrometer. All NMR spectra were recorded at $25{ }^{\circ} \mathrm{C}$, processed using Bruker Topspin 3.5 software and referenced to residual nondeuterated solvent signals (DMSO- $d_{6}: \delta_{\mathrm{H}} 2.49, \delta_{\mathrm{C}} 39.5 \mathrm{ppm}$ ).

\section{Collection and cultivation}

A. nanangensis MST-FP2251 was isolated by serial dilution of an aqueous suspension of soil collected in Nanango, Queensland, Australia in 2004. Cultures were freeze-dried and accessioned into the CSIRO Agriculture and Food (FRR) culture collection, North Ryde, NSW, Australia, with the code FRR6048. The growth of A. nanangensis was optimised on four different agar and liquid media and four types of grains. Agar and liquid versions of glycerol casein (AC), Czapek-Dox (CZ), malt extract (MA) and yeast extract (YS) media, and the grains, pearl barley (PB), cracked wheat (BL), jasmine rice (JR) and basmati rice (BS) were prepared in accordance with recipes provided in Table $\mathrm{S} 1$ in Supporting Information File 1. The culture was recovered from storage at $-80{ }^{\circ} \mathrm{C}$ onto three malt agar plates. At day 7 the recovery plates showed good confluent growth and no signs of contamination. Agar plates were sliced and deposited into three Erlenmeyer flasks containing sterilised Milli-Q water $(100 \mathrm{~mL})$. A spore suspension was created by shaking for $1 \mathrm{~h}$ prior to inoculation. The agar plates were inoculated with spore suspension $(500 \mu \mathrm{L})$, liquid media $(50 \mathrm{~mL})$ 
were inoculated with spore suspension $(2 \mathrm{~mL})$, and grains were inoculated with spore suspension $(10 \mathrm{~mL})$. The grain, agar and liquid media were placed in a dark room at $24{ }^{\circ} \mathrm{C}$, with the liquid media flasks on a shaker pad rotating at $90 \mathrm{rpm}$. The grains and agar cultivars were sub-sampled on days 7, 14 and 21 , while the liquids were sub-sampled on day 7 . The sub-samples were extracted in $\mathrm{MeOH}$ for $2 \mathrm{~h}$ prior to being analysed by analytical HPLC $\left(\mathrm{C}_{18}\right)$ to determine the secondary metabolite profile.

\section{Preparative cultivation, extraction and isolation}

Two preparative-scale cultivations were carried out to produce sufficient quantities of the nanangenine family for characterisation and bioassay. Cultivation conditions were identical with the exception of growth medium. Culture A was prepared with jasmine rice $(1.5 \mathrm{~kg})$ and Culture B with pearl barley $(1.5 \mathrm{~kg})$. Each grain was hydrated during sterilisation $\left(1 \mathrm{~L}\right.$ water; $120{ }^{\circ} \mathrm{C}$ for $40 \mathrm{~min}$ ). A spore suspension of a 7-day-old Petri plate of A. nanangensis was used to inoculate $42 \times 250 \mathrm{~mL}$ Erlenmeyer flasks each containing $75 \mathrm{~g}$ of sterile medium. The flasks were incubated at $24{ }^{\circ} \mathrm{C}$ for 21 days, by which time the cultures had grown extensively throughout the grain and reached maximal metabolite productivity. Cultures were extracted separately using the same process (see Figures S1 and S2 in Supporting Information File 1). Grains were pooled from individual flasks, and extracted with acetone $(2 \times 3 \mathrm{~L})$. The combined extracts were evaporated under vacuum to produce an aqueous slurry $(500 \mathrm{~mL})$. The slurry was partitioned against ethyl acetate $(2 \times 2 \mathrm{~L})$ and the ethyl acetate was reduced in vacuo to an oily residue. The residue was dissolved in methanol $(300 \mathrm{~mL})$ and defatted using hexanes $(2 \times 500 \mathrm{~mL})$ to give the crude extract.

Initial fractionation of culture A (13.5 g) was achieved using Sephadex LH-20 size-exclusion chromatography in methanol $(25 \times 600 \mathrm{~mm})$. The crude extract was loaded onto the column and eluted with methanol at a flow rate of $4 \mathrm{~mL} \mathrm{~min}{ }^{-1}$. The fractions $(100 \mathrm{~mL})$ were sub-sampled and analysed by $\mathrm{C}_{18}$ analytical HPLC. Fractions 3 and 4 were pooled and evaporated to give a solid residue $(3.7 \mathrm{~g})$, as were fractions 5-7 (7.8 g). Fraction 3-4 was dissolved in $\mathrm{MeOH}(8 \mathrm{~mL})$ and insoluble material was pelleted by centrifugation (4000 rpm for $7 \mathrm{~min}$ ). The supernatant was fractionated by preparative HPLC (Hypersil $\mathrm{C}_{18}$, isocratic $70 \% \mathrm{MeCN} / \mathrm{H}_{2} \mathrm{O}, 60 \mathrm{~mL} \mathrm{~min}{ }^{-1}$ ) to give an enriched fraction $(302.4 \mathrm{mg}$ ), which was further purified by preparative HPLC (Hypersil $\mathrm{C}_{18}$, isocratic $55 \% \mathrm{MeCN} / \mathrm{H}_{2} \mathrm{O}, 60 \mathrm{~mL} \mathrm{~min}^{-1}$ ) to yield nanangenine $\mathrm{B}\left(2 ; t_{\mathrm{R}}=41.0 \mathrm{~min} ; 92.1 \mathrm{mg}\right)$. Fraction 5-7 was dissolved in $\mathrm{MeOH}(9 \mathrm{~mL})$ and insoluble material was pelleted by centrifugation (4000 rpm for $7 \mathrm{~min}$ ). The supernatant was fractionated by preparative HPLC (Hypersil $\mathrm{C}_{18}$, isocratic $45 \% \mathrm{MeCN} / \mathrm{H}_{2} \mathrm{O}$ containing $0.01 \%$ TFA, $60 \mathrm{~mL} \mathrm{~min}^{-1}$ ) which yielded four subfractions (1, 3, 4 and 7) regarded as candidates for further purification. Subfraction 1 (337.8 mg) was purified by preparative HPLC (Hypersil $\mathrm{C}_{18}$, isocratic $27.5 \% \mathrm{MeCN} / \mathrm{H}_{2} \mathrm{O}$ containing $0.01 \% \mathrm{TFA}$, $\left.60 \mathrm{~mL} \mathrm{~min}^{-1}\right)$ to give an enriched fraction $(53.2 \mathrm{mg})$, which was further fractionated by preparative HPLC (Alltima $\mathrm{C}_{18}$, isocratic $25 \% \mathrm{MeCN} / \mathrm{H}_{2} \mathrm{O}$ containing $0.01 \% \mathrm{TFA}$, $\left.60 \mathrm{~mL} \mathrm{~min}{ }^{-1}\right)$ to yield nanangenine A $\left(1 ; t_{\mathrm{R}}=12.6 \mathrm{~min}\right.$; $25.9 \mathrm{mg})$. Subfraction $3(942.1 \mathrm{mg})$ was purified by preparative HPLC (Hypersil $\mathrm{C}_{18}$, isocratic 55\% $\mathrm{MeCN} / \mathrm{H}_{2} \mathrm{O}, 60 \mathrm{~mL} \mathrm{~min}{ }^{-1}$ ) to give an enriched fraction, which was further fractionated by preparative HPLC (Alltima $\mathrm{C}_{18}$, isocratic $50 \% \mathrm{MeCN} / \mathrm{H}_{2} \mathrm{O}$, $\left.60 \mathrm{~mL} \mathrm{~min}{ }^{-1}\right)$ to yield nanangenine $\mathrm{G}\left(\mathbf{9} ; t_{\mathrm{R}}=16.5 \mathrm{~min}\right.$; $211.3 \mathrm{mg})$. Subfraction $4(632.0 \mathrm{mg})$ was purified by preparative HPLC (Hypersil $\mathrm{C}_{18}$, isocratic $60 \% \mathrm{MeCN} / \mathrm{H}_{2} \mathrm{O}$, $60 \mathrm{~mL} \mathrm{~min}-1)$ to yield isonanangenine $\mathrm{B}\left(3 ; t_{\mathrm{R}}=19.1 \mathrm{~min}\right.$; $106.3 \mathrm{mg})$. Subfraction $7(490.1 \mathrm{mg})$ was purified by preparative HPLC (Hypersil $\mathrm{C}_{18}$, isocratic $80 \% \mathrm{MeCN} / \mathrm{H}_{2} \mathrm{O}$ contain-

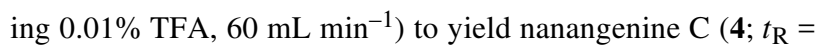
$11.5 \mathrm{~min} ; 117.4 \mathrm{mg}$ ).

Initial fractionation of culture B (13.5 g) was achieved using $100 \mathrm{~g}$ silica gel (Davisil, Grace Discovery $50 \mu \mathrm{m}$ ) with $20 \mathrm{~g}$ of silica used to dry load the sample atop the column bed $(55 \times 250 \mathrm{~mm})$. The column was eluted with $\mathrm{CHCl}_{3}(500 \mathrm{~mL})$ containing increasing concentrations of $\mathrm{MeOH}$. The fractions containing terpenoids $(0-2 \% \mathrm{MeOH}, 3.0 \mathrm{~g})$ were pooled and fractionated using isocratic preparative HPLC (Zorbax $\mathrm{C}_{18}$, $\left.65 \% \mathrm{MeCN} / \mathrm{H}_{2} \mathrm{O}, 60 \mathrm{~mL} \mathrm{~min}{ }^{-1}\right)$ to give five fractions containing terpenoids. Fraction $1(785.3 \mathrm{mg})$ was purified by isocratic preparative HPLC (Zorbax $\mathrm{C}_{18}$, isocratic $45 \% \mathrm{MeCN} / \mathrm{H}_{2} \mathrm{O}$, $\left.20 \mathrm{~mL} \mathrm{~min}^{-1}\right)$ to yield nanangenine $\mathrm{H}\left(\mathbf{1 2} ; t_{\mathrm{R}}=15.6 \mathrm{~min}\right.$; $41.7 \mathrm{mg}$ ). Fraction $2(93.7 \mathrm{mg})$ was purified by isocratic preparative HPLC (Zorbax $\mathrm{C}_{18}$, isocratic $70 \% \mathrm{MeCN} / \mathrm{H}_{2} \mathrm{O}$, $\left.20 \mathrm{~mL} \mathrm{~min}^{-1}\right)$ to yield nanangenine $\mathrm{F}\left(\mathbf{8} ; t_{\mathrm{R}}=12.9 \mathrm{~min}\right.$; $7.2 \mathrm{mg}$ ). Fraction $3(30.6 \mathrm{mg}$ ) was purified by isocratic preparative HPLC (Zorbax $\mathrm{C}_{18}$, isocratic $70 \% \mathrm{MeCN} / \mathrm{H}_{2} \mathrm{O}$,

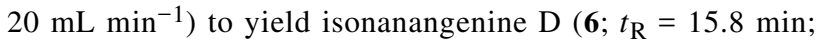
$10.7 \mathrm{mg}$ ). Fraction $4(48.8 \mathrm{mg})$ was purified by isocratic preparative HPLC (Zorbax $\mathrm{C}_{18}$, isocratic $70 \% \mathrm{MeCN} / \mathrm{H}_{2} \mathrm{O}$, $\left.20 \mathrm{~mL} \mathrm{~min}^{-1}\right)$ to yield nanangenine $\mathrm{D}\left(\mathbf{5} ; t_{\mathrm{R}}=21.8 \mathrm{~min} ; 29.9\right.$ $\mathrm{mg})$. Fraction $5(24.4 \mathrm{mg}$ ) was purified by isocratic preparative HPLC (Zorbax $\mathrm{C}_{18}$, isocratic $75 \% \mathrm{MeCN} / \mathrm{H}_{2} \mathrm{O}, 20 \mathrm{~mL} \mathrm{~min}{ }^{-1}$ ) to yield nanangenine $\mathrm{E}\left(7 ; t_{\mathrm{R}}=12.8 \mathrm{~min} ; 8.7 \mathrm{mg}\right)$.

\section{Characterisation of compounds}

Nanangenine A (1): white powder; $[\alpha]_{\mathrm{D}}{ }^{20}-205(c 0.03$, $\mathrm{MeOH}) ; \mathrm{UV}(\mathrm{MeCN}) \lambda_{\max }(\log \varepsilon) 200$ (4.19); 212 (3.71) nm; HRMS-ESI $(+, m / z):[\mathrm{M}+\mathrm{Na}]^{+}$calcd. for $\mathrm{C}_{15} \mathrm{H}_{22} \mathrm{NaO}_{5}{ }^{+}$, 305.1359; found, 305.1363 . 
Nanangenine B (2): white powder; $[\alpha]_{\mathrm{D}}{ }^{20}-226(c \quad 0.06$, $\mathrm{MeOH}) ; \mathrm{UV}(\mathrm{MeCN}) \lambda_{\max }(\log \varepsilon) 200$ (4.08); 208 (3.76) nm; HRMS-ESI $(+, m / z):[\mathrm{M}+\mathrm{Na}]^{+}$calcd. for $\mathrm{C}_{21} \mathrm{H}_{32} \mathrm{NaO}_{6}{ }^{+}$, 403.2091; found, 403.2096.

Isonanangenine $\mathbf{B}(3)$ : white powder; $[\alpha]_{\mathrm{D}}{ }^{20}-180(c 0.04$, $\mathrm{MeOH}) ; \mathrm{UV}(\mathrm{MeCN}) \lambda_{\max }(\log \varepsilon) 200$ (4.42); 207 (4.21) nm; HRMS-ESI $(+, m / z):[\mathrm{M}+\mathrm{Na}]^{+}$calcd. for $\mathrm{C}_{21} \mathrm{H}_{32} \mathrm{NaO}_{6}{ }^{+}$, 403.2091; found, 403.2094.

Nanangenine C (4): white powder; $[\alpha]_{\mathrm{D}}{ }^{20}-289$ (c 0.2 , $\mathrm{MeOH}) ; \mathrm{UV}(\mathrm{MeCN}) \lambda_{\max }(\log \varepsilon) 200$ (4.09); 208 (3.91) nm. HRMS-ESI $(+, m / z):[\mathrm{M}+\mathrm{Na}]^{+}$calcd. for $\mathrm{C}_{21} \mathrm{H}_{32} \mathrm{NaO}_{5}{ }^{+}$, 387.2142 ; found, 387.2147 .

Nanangenine D (5): white powder; $[\alpha]_{\mathrm{D}}{ }^{24}-246$ (c 0.28 , $\mathrm{MeOH})$; UV (MeCN) $\lambda_{\max }(\log \varepsilon) 200$ (3.90); 208 (3.81) nm; HRMS-ESI $(+, m / z):[\mathrm{M}+\mathrm{H}]^{+}$calcd. for $\mathrm{C}_{23} \mathrm{H}_{37} \mathrm{O}_{6}{ }^{+}$, 409.2585; found, 409.2579 .

Isonanangenine $\mathbf{D}(6)$ : white powder; $[\alpha]_{\mathrm{D}}{ }^{24}-234(c) 0.13$, $\mathrm{MeOH})$; UV (MeCN) $\lambda_{\max }(\log \varepsilon) 200$ (4.47); 206.5 (4.42) nm; HRMS-ESI $(+, m / z):[\mathrm{M}+\mathrm{H}]^{+}$calcd. for $\mathrm{C}_{23} \mathrm{H}_{37} \mathrm{O}_{6}{ }^{+}$, 409.2585; found, 409.2581.

Nanangenine E (7): white powder; $[\alpha]_{\mathrm{D}}{ }^{24}-285$ (c 0.18 , $\mathrm{MeOH})$; UV (MeCN) $\lambda_{\max }(\log \varepsilon) 200$ (4.17); 206.5 (4.08) nm; HRMS-ESI $(+, m / z):[\mathrm{M}+\mathrm{H}]^{+}$calcd. for $\mathrm{C}_{23} \mathrm{H}_{37} \mathrm{O}_{5}{ }^{+}$, 393.2636; found, 393.2628.

Nanangenine F (8): white powder; $[\alpha]_{\mathrm{D}}{ }^{24}-268$ (c 0.24 , $\mathrm{MeOH}) ; \mathrm{UV}(\mathrm{MeCN}) \lambda_{\max }(\log \varepsilon) 200$ (3.96); 203 (3.82) nm; HRMS-ESI $(+, m / z):[\mathrm{M}+\mathrm{H}]^{+}$calcd. for $\mathrm{C}_{21} \mathrm{H}_{35} \mathrm{O}_{5}{ }^{+}[\mathrm{M}+\mathrm{H}]^{+}$, 367.2479; found, 367.2483 .

Nanangenine G (9): white powder; $[\alpha]_{\mathrm{D}}{ }^{20}-231$ (c 0.05 , $\mathrm{MeOH})$; UV (MeCN) $\lambda_{\max }(\log \varepsilon) 200$ (4.17) nm; HRMS-ESI $(+, m / z):[\mathrm{M}+\mathrm{Na}]^{+}$calcd. for $\mathrm{C}_{21} \mathrm{H}_{36} \mathrm{NaO}_{6}{ }^{+}[\mathrm{M}+\mathrm{Na}]^{+}$, 407.2404; found, 407.2406.

Nanangenine H (10): white powder; $[\alpha]_{\mathrm{D}}{ }^{24}-270(c 0.13$, $\mathrm{MeOH}) ; \mathrm{UV}(\mathrm{MeCN}) \lambda_{\max }(\log \varepsilon) 200(3.98) \mathrm{nm}$; HRMS-ESI $(+, m / z):\left[\mathrm{M}-\mathrm{H}_{2} \mathrm{O}+\mathrm{H}\right]^{+}$calcd. for $\mathrm{C}_{22} \mathrm{H}_{35} \mathrm{O}_{5}{ }^{+}\left[\mathrm{M}-\mathrm{H}_{2} \mathrm{O}+\right.$ $\mathrm{H}]^{+}$, 379.2479; found, 379.2473.

\section{Crystallography}

Crystals suitable for single crystal X-ray diffraction analysis were obtained for $\mathbf{1}, \mathbf{4}$ and $\mathbf{9}$, providing confirmation of the spectroscopic structural elucidation. Indirect confirmation of the structures of $\mathbf{2}$ and $\mathbf{3}$ was obtained following their conversion to 4-bromobenzoyl ester derivatives, with substitution at the C-9 and $\mathrm{C}-1$ hydroxy groups respectively, and the growth of crystals of these derivatives ( $\mathbf{2} \mathbf{b}$ and $\mathbf{3 b}$ ). The X-ray diffraction data obtained from single crystals of $\mathbf{4}$ and $\mathbf{9}$ did not allow a definitive determination of their absolute structures, however their anomalous dispersion statistics indicate that the assignments are very likely to be correct. The crystal structure of $\mathbf{1}$ has four crystallographically-independent molecules, while the structures of $\mathbf{2} \mathbf{b}$ and $\mathbf{3 b}$ have two crystallographically-independent molecules, and the structures of $\mathbf{4}$ and $\mathbf{9}$ have one. The cyclohexane rings of all molecules have chair conformations, the cyclohexene rings of all molecules have half-chair conformations, and the furan rings of all molecules have flattened envelope conformations. See Supporting Information File 1 for detailed methods.

\section{Genomics and bioinformatic analysis}

Genomic DNA was extracted from A. nanangensis (see Supporting Information File 1) and sent to the Australian Genome Research Facilities for de novo genome sequencing using Illumina HiSeq 2000. A draft genome assembly of A. nanangensis was obtained using SPAdes v3.13.0 via the AAFTF pipeline (https://github.com/stajichlab/AAFTF). To facilitate the identification of a putative biosynthetic gene cluster, a local BLAST database was created from the resulting assembly [44]. Though Shinohara et al. list the revised annotation of AstC as AORIB40_05408, its amino acid sequence of was retrieved from AspGD [45] under the locus tag AO090026000582. AstC homologs were identified in A. nanangensis via the tBLASTn [44] functionality in Geneious 10.2.6 [46]. The genome sequences for drimane sesquiterpenoid producing Aspergilli were obtained from NCBI where available. This included A. calidoustus SF006504 (GCA_001511075.1), A. ochraceus fc-1 (GCA_004849945.1), A. parasiticus SU-1 (GCA_000956085.1), A. sclerotiorum HBR18 (GCA_000530345.1) and A. ustus 3.3904 (GCA_000812125.1). Homologous gene clusters were identified in these genomes using a custom Python script, named clusterblaster (https:// github.com/gamcil/clusterblaster). A DIAMOND [47] database was built from protein sequences extracted from these genomes, and clusterblaster was used to rapidly identify biosynthetic gene cluster homologs in A. ustus and A. calidoustus. Genomes for A. insuetus CBS 107.25 and A. pseudodeflectus CBS 756.74 were obtained from the Joint Genome Institute (JGI) under genome portals Aspins1 and Asppdef1, respectively. Manual tBLASTn searches using the putative nanangenine biosynthetic gene cluster sequences were performed to identify homologs in these genomes. Homology between these clusters was visualised using another custom Python script named crosslinker (https://github.com/gamcil/crosslinker). Further details regarding clusterblaster and crosslinker are given in Supporting Information File 1. 


\section{Supporting Information}

\section{Supporting Information File 1}

Details of cultivation media, fractionation schemes, NMR spectra and tabulated 2D NMR data for all compounds, detailed X-ray crystallographic details and CCDC deposition numbers, bioassay procedures and genomic data. [https://www.beilstein-journals.org/bjoc/content/ supplementary/1860-5397-15-256-S1.pdf]

\section{Supporting Information File 2}

Crystal structure information files for nanangenines A-C and $\mathrm{G}$.

[https://www.beilstein-journals.org/bjoc/content/ supplementary/1860-5397-15-256-S2.zip]

\section{Acknowledgements}

We thank Dr Matthew McKay (MQ) and Dr Nick Proschogo (USyd) for acquisition of HRMS data, Dr Ian Luck (USyd) for acquisition of preliminary NMR data and Si Shu (UWA) for preparation of genomic DNA for genome sequencing. This work was funded, in part, by the Australian Research Council (FT130100142, FT160100233) and the Cooperative Research Centres Projects scheme (CRCPFIVE000119).

\section{ORCID ${ }^{\circledR}$ iDs}

Peter J. Rutledge - https://orcid.org/0000-0002-0767-5196

Ernest Lacey - https://orcid.org/0000-0002-5387-2721

Yit-Heng Chooi - https://orcid.org/0000-0001-7719-7524

Andrew M. Piggott - https://orcid.org/0000-0002-5308-5314

\section{References}

1. Heddergott, C.; Calvo, A. M.; Latgé, J. P. Eukaryotic Cell 2014, 13, 1014-1025. doi:10.1128/ec.00074-14

2. Huang, J.-H.; Lv, J.-M.; Wang, Q.-Z.; Zou, J.; Lu, Y.-J.; Wang, Q.-L.; Chen, D.-N.; Yao, X.-S.; Gao, H.; Hu, D. Org. Biomol. Chem. 2019, 17, 248-251. doi:10.1039/c8ob02832j

3. Liu, X.-H.; Miao, F.-P.; Qiao, M.-F.; Cichewicz, R. H.; Ji, N.-Y. RSC Adv. 2013, 3, 588-595. doi:10.1039/c2ra22701k

4. Felix, S.; Sandjo, L. P.; Opatz, T.; Erkel, G. Beilstein J. Org. Chem. 2013, 9, 2866-2876. doi:10.3762/bjoc.9.323

5. Felix, S.; Sandjo, L. P.; Opatz, T.; Erkel, G. Bioorg. Med. Chem. 2014, 22, 2912-2918. doi:10.1016/j.bmc.2014.04.015

6. de Souza, J. J.; Vieira, I. J. C.; Rodrigues-Filho, E.; Braz-Filho, R. Molecules 2011, 16, 10604-10618. doi:10.3390/molecules161210604

7. Cueto, M.; Jensen, P. R.; Fenical, W. Org. Lett. 2002, 4, 1583-1585. doi:10.1021/ol0258076

8. Hensens, O. D.; Zink, D.; Williamson, J. M.; Lotti, V. J.; Chang, R. S. L.; Goetz, M. A. J. Org. Chem. 1991, 56, 3399-3403. doi:10.1021/jo00010a040

9. Zhang, D.; Fukuzawa, S.; Satake, M.; Li, X.; Kuranaga, T.; Niitsu, A.; Yoshizawa, K.; Tachibana, K. Nat. Prod. Commun. 2012, 7, 1411-1414. doi:10.1177/1934578x1200701102
10. Afiyatullov, S.; Zhuravleva, O. I.; Antonov, A. S.; Kalinovsky, A. I.; Pivkin, M. V.; Menchinskaya, E. S.; Aminin, D. L. Nat. Prod. Commun. 2012, 7, 497-500. doi:10.1177/1934578x1200700421

11. Bai, Z.-Q.; Lin, X.; Wang, J.; Zhou, X.; Liu, J.; Yang, B.; Yang, X.; Liao, S.; Wang, L.; Liu, Y. Mar. Drugs 2015, 13, 237-248. doi:10.3390/md13010237

12. Liaw, C.-C.; Yang, Y.-L.; Lin, C.-K.; Lee, J.-C.; Liao, W.-Y.; Shen, C.-N.; Sheu, J.-H.; Wu, S.-H. Org. Lett. 2015, 17, 2330-2333. doi:10.1021/acs.orglett.5b00739

13. Liu, Z.; Liu, H.; Chen, Y.; She, Z. Nat. Prod. Res. 2018, 32, 2652-2656. doi:10.1080/14786419.2017.1375924

14. Qi, C.; Bao, J.; Wang, J.; Zhu, H.; Xue, Y.; Wang, X.; Li, H.; Sun, W.; Gao, W.; Lai, Y.; Chen, J.-G.; Zhang, Y. Chem. Sci. 2016, 7, 6563-6572. doi:10.1039/c6sc02464e

15. Shaaban, M.; El-Metwally, M. M.; Abdel-Razek, A. A.; Laatsch, H. Nat. Prod. Res. 2018, 32, 2437-2446. doi:10.1080/14786419.2017.1419230

16. Liu, H.; Edrada-Ebel, R.; Ebel, R.; Wang, Y.; Schulz, B.; Draeger, S.; Müller, W. E. G.; Wray, V.; Lin, W.; Proksch, P. J. Nat. Prod. 2009, 72, 1585-1588. doi:10.1021/np900220r

17. Kozlovskii, A. G.; Antipova, T. V.; Zhelifonova, V. P.; Baskunov, B. P.; Ivanushkina, N. E.; Kochkina, G. A.; Ozerskaya, S. M. Microbiology (Moscow, Russ. Fed.) 2017, 86, 176-182. doi:10.1134/s0026261717020114

18. Rahbæk, L.; Christophersen, C.; Frisvad, J.; Bengaard, H. S.; Larsen, S.; Rassing, B. R. J. Nat. Prod. 1997, 60, 811-813. doi:10.1021/np970142f

19. Gould, R. O.; Simpson, T. J.; Walkinshaw, M. D. Tetrahedron Lett. 1981, 22, 1047-1050. doi:10.1016/s0040-4039(01)82862-8

20. Hamasaki, T.; Kuwano, H.; Isono, K.; Hatsuda, Y.; Fukuyama, K.; Tsukihara, T.; Katsube, Y. Agric. Biol. Chem. 1975, 39, 749-751. doi:10.1080/00021369.1975.10861681

21. Shinohara, Y.; Takahashi, S.; Osada, H.; Koyama, Y. Sci. Rep. 2016, 6, 32865. doi:10.1038/srep32865

22. Fang, W.; Lin, X.; Zhou, X.; Wan, J.; Lu, X.; Yang, B.; Ai, W.; Lin, J.; Zhang, T.; Tu, Z.; Liu, Y. Med. Chem. Commun. 2014, 5, 701-705. doi:10.1039/c3md00371j

23. Zhuravleva, O. I.; Afiyatullov, S. S.; Denisenko, V. A.; Ermakova, S. P.; Slinkina, N. N.; Dmitrenok, P. S.; Kim, N. Y. Phytochemistry 2012, 80, 123-131. doi:10.1016/j.phytochem.2012.05.008

24. Jansen, B. J. M.; de Groot, A. Nat. Prod. Rep. 2004, 21, 449-477. doi:10.1039/b311170a

25. Chaudhary, N. K.; Pitt, J. I.; Lacey, E.; Crombie, A.; Vuong, D.; Piggott, A. M.; Karuso, P. J. Nat. Prod. 2018, 81, 1517-1526. doi:10.1021/acs.jnatprod.7b00816

26. Lacey, H. J.; Vuong, D.; Pitt, J. I.; Lacey, E.; Piggott, A. M. Aust. J. Chem. 2016, 69, 152-160. doi:10.1071/ch15488

27. Li, H.; Gilchrist, C. L. M.; Lacey, H. J.; Crombie, A.; Vuong, D.; Pitt, J. I.; Lacey, E.; Chooi, Y.-H.; Piggott, A. M. Org. Lett. 2019, 21, 1287-1291. doi:10.1021/acs.orglett.8b04042

28. Pitt, J. I.; Lange, L.; Lacey, A. E.; Vuong, D.; Midgley, D. J.; Greenfield, P.; Bradbury, M. I.; Lacey, E.; Busk, P. K.; Pilgaard, B.; Chooi, Y.-H.; Piggott, A. M. PLoS One 2017, 12, e0170254. doi:10.1371/journal.pone.0170254

29. Shiono, Y.; Hiramatsu, F.; Murayama, T.; Koseki, T.; Funakoshi, T.; Ueda, K.; Yasuda, H. Z. Z. Naturforsch., B: J. Chem. Sci. 2007, 62, 1585-1589. doi:10.1515/znb-2007-1218

30. Gao, Y.; Honzatko, R. B.; Peters, R. J. Nat. Prod. Rep. 2012, 29 , 1153-1175. doi:10.1039/c2np20059g 
31. Hitchman, T. S.; Schmidt, E. W.; Trail, F.; Rarick, M. D.; Linz, J. E.; Townsend, C. A. Bioorg. Chem. 2001, 29, 293-307. doi:10.1006/bioo.2001.1216

32. Lin, H.-C.; Chooi, Y.-H.; Dhingra, S.; Xu, W.; Calvo, A. M.; Tang, Y. J. Am. Chem. Soc. 2013, 135, 4616-4619. doi:10.1021/ja312503y

33. Christianson, D. W. Chem. Rev. 2006, 106, 3412-3442. doi:10.1021/cr050286w

34. Nakano, C.; Okamura, T.; Sato, T.; Dairi, T.; Hoshino, T. Chem. Commun. 2005, 1016-1018. doi:10.1039/b415346d

35. Cao, R.; Zhang, Y.; Mann, F. M.; Huang, C.; Mukkamala, D.; Hudock, M. P.; Mead, M. E.; Prisic, S.; Wang, K.; Lin, F.-Y.; Chang, T.-K.; Peters, R. J.; Oldfield, E. Proteins: Struct., Funct., Bioinf. 2010, 78, 2417-2432. doi:10.1002/prot.22751

36. Nakano, C.; Hoshino, T. ChemBioChem 2009, 10, 2060-2071. doi:10.1002/cbic.200900248

37. Lu, Z.; Wang, Y.; Miao, C.; Liu, P.; Hong, K.; Zhu, W. J. Nat. Prod. 2009, 72, 1761-1767. doi:10.1021/np900268z

38. Zhou, H.; Zhu, T.; Cai, S.; Gu, Q.; Li, D. Chem. Pharm. Bull. 2011, 59, 762-766. doi:10.1248/cpb.59.762

39. Cohen, E.; Koch, L.; Thu, K. M.; Rahamim, Y.; Aluma, Y.; Ilan, M.; Yarden, O.; Carmeli, S. Bioorg. Med. Chem. 2011, 19, 6587-6593. doi:10.1016/j.bmc.2011.05.045

40. Hayes, M. A.; Wrigley, S. K.; Chetland, I. A. N.; Reynolds, E. E.; Ainsworth, A. M.; Renno, D. V.; Latif, M. A.; Cheng, X.-M.; Hupe, D. J.; Charlton, P.; DoHerty, A. M. J. Antibiot. 1996, 49, 505-512. doi:10.7164/antibiotics.49.505

41. Slack, G. J.; Puniani, E.; Frisvad, J. C.; Samson, R. A.; Miller, J. D. Mycol. Res. 2009, 113, 480-490. doi:10.1016/j.mycres.2008.12.002

42. Curlevski, N. J. A.; Xu, Z.; Anderson, I. C.; Cairney, J. W. G. J. Soils Sediments 2010, 10, 1278-1288. doi:10.1007/s11368-010-0239-x

43. Gao, X.; Xie, X.; Pashkov, I.; Sawaya, M. R.; Laidman, J.; Zhang, W.; Cacho, R.; Yeates, T. O.; Tang, Y. Chem. Biol. 2009, 16, 1064-1074. doi:10.1016/j.chembiol.2009.09.017

44. Camacho, C.; Coulouris, G.; Avagyan, V.; Ma, N.; Papadopoulos, J.; Bealer, K.; Madden, T. L. BMC Bioinf. 2009, 10, 421. doi:10.1186/1471-2105-10-421

45. Cerqueira, G. C.; Arnaud, M. B.; Inglis, D. O.; Skrzypek, M. S.; Binkley, G.; Simison, M.; Miyasato, S. R.; Binkley, J.; Orvis, J.; Shah, P.; Wymore, F.; Sherlock, G.; Wortman, J. R. Nucleic Acids Res. 2014, 42, D705-710. doi:10.1093/nar/gkt1029

46. Kearse, M.; Moir, R.; Wilson, A.; Stones-Havas, S.; Cheung, M.; Sturrock, S.; Buxton, S.; Cooper, A.; Markowitz, S.; Duran, C.; Thierer, T.; Ashton, B.; Meintjes, P.; Drummond, A. Bioinformatics 2012, 28, 1647-1649. doi:10.1093/bioinformatics/bts199

47. Buchfink, B.; Xie, C.; Huson, D. H. Nat. Methods 2015, 12, 59-60. doi:10.1038/nmeth.3176

\section{License and Terms}

This is an Open Access article under the terms of the Creative Commons Attribution License (http://creativecommons.org/licenses/by/4.0). Please note that the reuse, redistribution and reproduction in particular requires that the authors and source are credited.

The license is subject to the Beilstein Journal of Organic Chemistry terms and conditions:

(https://www.beilstein-journals.org/bjoc)

The definitive version of this article is the electronic one which can be found at:

doi:10.3762/bjoc. 15.256 